\title{
Pengaruh Penggunaan Fly Ash dan Bottom Ash sebagai Cover dalam Pencegahan Pembentukan Air Asam Tambang Menggunakan Metode Free Draining Column Leach Test
}

\author{
Muhammad Farhan ${ }^{1}$ dan Candra Nugraha ${ }^{1}$ \\ ${ }^{1}$ Jurusan Teknik Lingkungan, Fakultas Teknik Sipil dan Perencanaan, ITENAS, Bandung \\ Email: muhamaddfarhann42@gmail.com
}

Received 30 November 201x | Revised 30 Desember 201x | Accepted 30 Januari $201 x$

\begin{abstract}
ABSTRAK
Upaya pencegahan pembentukan air asam tambang dapat dilakukan dengan metode dry cover yang dilakukan dengan menutup batuan yang berpotensi membentuk asam (PAF) dengan batuan yang tidak berpotensi membentuk asam (NAF). Penelitian ini bertujuan untuk mengetahui pengaruh penggunaan fly ash dan bottom ash sebagai NAF dalam mencegah pembentukan AAT dengan cara mengurangi kontak antara mineral sulfida dengan air dan oksigen. Metode Free Draining Column Leach Test digunakan untuk memprediksi pembentukan AAT yang terbentuk. Simulasi perbedaan perlakuan sampel digunakan dengan 2 variasi pelapisan sampel NAF dan 3 variasi pencampuran sampel NAF. Hasil simulasi menunjukkan bahwa dengan variasi pelapisan sampel NAF didapatkan kualitas air yang lebih baik. Penggunaan variasi pelapisan meningkatkan nilai pH, menurunkan nilai TDS serta DHL sebagai hasil oksidasi pirit didalam batuan. Untuk menunjang hasil analisis kualitas air, pengujian statistika juga digunakan untuk mengetahui perbedaan dari variasi penggunaan fly ash dan bottom ash terhadap perubahan nilai $p H, T D S$ dan DHL yang dihasilkan.
\end{abstract}

Kata kunci : Fly ash, Bottom ash, $p H, T D S, D H L$

\begin{abstract}
Acid mine drainage prevention efforts can be carried out by the method of the dry cover which is done by closing the rock that is potentially acid forming (PAF) with the non-potentially acid forming rock (NAF). This study aims to determine the effect of the fly ash and bottom ash as NAF in preventing the formation of AMD by reduce contact between the sulfide minerals with water and oxygen. The method of Free Draining Column Leach Test is used to predict the formation of AMD formed. Simulated difference in sample treatment is used with 2 variations in the coating samples of NAF and 3 variations of the mixing a sample of NAF. The simulation results show that with the variation of the coating sample of NAF obtained better water quality. The use of variations of the coating increases $p H$ value, lower the value of TDS as well as DHL as a result of oxidation of pyrite. To support the results of water quality analysis, the statistics test is also used to determine the difference from the variation of the use of fly ash and bottom ash to change the pH value, TDS and DHL that is produced.
\end{abstract}

Keywords: Fly ash, Bottom ash, $p H, T D S, D H L$ 


\section{PENDAHULUAN}

Air asam tambang (AAT) yang dikenal dengan acid mine drainage (AMD) adalah air yang berasal dari kegiatan penambangan yang bersifat asam yang terbentuk sebagai hasil dari oksidasi mineral sulfida dengan keberadaan air. Sumber keasaman dalam pembentukan air asam tambang adalah mineral sulfida dengan pengoksidasinya berupa oksigen. Air dalam pembentukan air asam tambang merupakan media yang membawa hasil oksidasi. Perubahan kualitas air yang membawa hasil oksidasi mineral sulfida tersebut memiliki nilai keasaman yang tinggi sehingga disebut sebagai air asam tambang [1].

Salah satu masalah serius yang ditimbulkan akibat dari terbentuknya air asam tambang adalah pencemaran air. Air asam tambang yang terbentuk jika mengalir ke badan air dapat menjadi polutan beracun terhadap organisme yang ada diperairan. Air yang sudah tercemar air asam tambang mengakibatkan kerusakan korosi terhadap peralatan tambang dan pipa saluran air untuk irigasi maupun pipa saluran untuk air minum.. Selain itu, air asam tambang juga menjadi permasalahan serius apabila tidak ditangani dengan baik. Air asam tambang akan tetap terbentuk walaupun kegiatan operasional tambang sudah berhenti operasi [1].

Penanganan yang dapat dilakukan untuk mencegah terbentuknya air asam tambang dapat dilakukan menggunakan metode enkapsulasi. Dalam metode ini dilakukan penutupan terhadap material pembentuk asam dengan material yang bukan pembentuk asam. Tujuan dari penutupan adalah untuk mencegah kontak antara komponen penyebab air asam tambang yaitu sulfida, air dan oksigen. Metode enkapsulasi yang umum digunakan adalah dry cover yang dilakukan dengan membuat lapisan kedap untuk menutupi batuan yang berpotensi membentuk asam sehingga infiltrasi air dan oksigen dapat diminimalisir agar tidak masuk ke dalam lapisan pembentuk asam. Fly ash dan bottom ash merupakan salah satu material yang memiliki potensi untuk dapat digunakan sebagai lapisan kedap untuk menghambat masuknya air dan oksigen sebagai komponen pembentuk air asam tambang. Dengan ukuran partikelnya yang kecil, fly ash dan bottom ash diharapkan dapat memperkecil infiltrasi air didalam batuan dan sifat alkali dari material ini diharapkan dapat menetralkan asam yang dihasilkan dari reaksi sulfida dengan air dan oksigen.

Penelitian ini bertujuan untuk mengetahui bagaimana pengaruh dari penggunaan material fly ash dan bottom ash sebagai cover material sulfida dalam batuan terhadap pencegahan pembentukan air asam tambang. Pengaruh dari penggunaan material tersebut akan dilihat pada kualitas air yang dihasilkan dengan melihat parameter $\mathrm{pH}$, TDS dan DHL dimana parameter tersebut berhubungan langsung dengan hasil oksidasi dari mineral sulfida pirit.

\section{METODOLOGI}

\subsection{Persiapan Aquades}

Kebutuhan aquades untuk penyiraman masing-masing tabung dapat dilihat pada tabel 1 berikut:

\subsection{Sampel}

Sampel fly ash yang digunakan dalam penelitian tidak diayak karena distribusi ukuran yang kecil $<75$ $\mathrm{mm}$. Sampel bottom ash dan pirit dalam penelitian ini diayak terlebih dahulu sebelum dimasukkan kedalam tabung. Sampel pirit dihaluskan menggunakan crusher, kemudian disaring untuk mendapatkan ukuran butiran sebesar $2 \mathrm{~mm}$. Sampel bottom ash juga disaring untuk mendapatkan ukuran butiran sebesar $-0,075 \mathrm{~mm}$. Penentuan ukuran butiran masing-masing sampel mengiktui referensi dari buku Sayoga, 2014 [2]. Penyaringan dan pemecahan sampel dilakukan agar sampel batuan 
memiliki distribusi ukuran yang merata dalam tabung dan untuk memperbesar luas permukaan reaktif sampel.

Tabel 1. Kebutuhan penyiraman aquades tiap tabung

\begin{tabular}{ccc}
\hline Tabung & Kebutuhan Aquades (L) & Variasi \\
\hline 1 & 1,8 & Pelapisan \\
2 & 1,2 & \\
3 & 1,2 & Pencampuran \\
5 & 1,8 & \\
7 & 1,8 & \\
9 & 0,8 & Kontrol \\
10 & 1,6 & \\
11 & 1,2 & \\
12 & 1,2 & \\
\hline
\end{tabular}

\subsection{Metode}

Percobaan uji kinetik free draining column leach test ini dilakukan dengan tabung reaktor berdiameter $16 \mathrm{~cm}$ dan tinggi $40 \mathrm{~cm}$. Setiap lapisan dalam tabung diisi dengan $10 \mathrm{~cm}$ sampel yang akan digunakan. Penentuan ukuran tabung disesuaikan dengan kebutuhan analisis karena tidak terdapat referensi pasti dalam penentuan ukuran tabung yang dapat digunakan. Dalam penelitian ini, ukuran tabung digunakan dengan menyesuaikan pada skala lab mengikuti referensi pada buku Sayoga, 2015 [3]. Tabung yang digunakan sebanyak 9 kolom yang terdiri dari 2 tabung variasi pelapisan NAF, 3 tabung variasi pencampuran fly ash dan bottom ash serta 4 tabung kontrol dari masing-masing sampel yang digunakan. Gambar skema dari variasi penelitian yang dilakukan dapat dilihat pada Gambar 1, Gambar 2 dan Gambar 3 berikut:

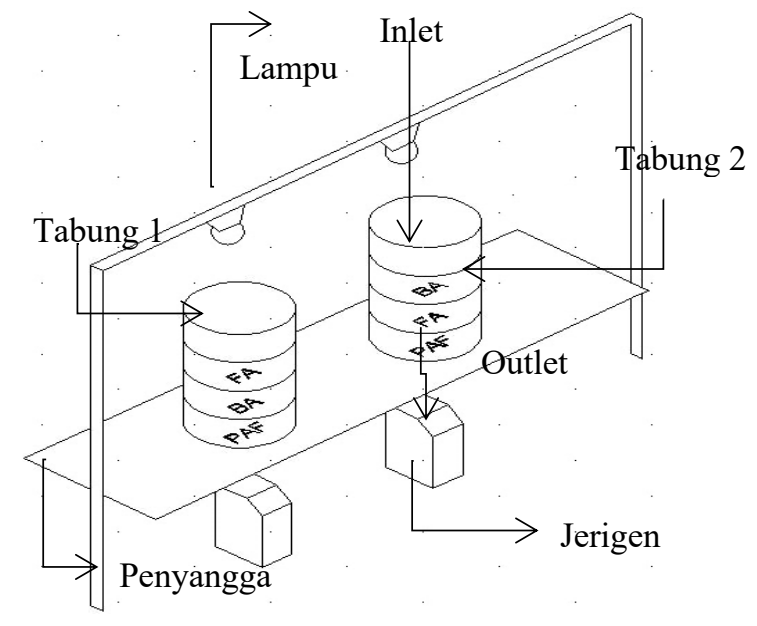

Gambar 1. Skema tabung pelapisan

Uji free draining column leach test yang dilakukan pada penelitian ini menerapkan sistem pelapisan dan pencampuran material NAF fly ash dan bottom ash dengan komposisi dan ketebalan tertentu. Air destilat dimasukkan ke dalam masing-masing tabung setiap hari selama 28 hari untuk mendapatkan hasil air lindian di hari berikutnya. Air destilat disiramkan dari atas permukaan tabung agar keseluruhan sampel di tiap lapisan akan di aliri oleh air. Kemudian dihari berikutnya air lindian yang keluar diukur kualitas air nya dari setiap tabung tersebut. Pengujian ini dilakukan selama 28 hari dengan siklus basah-kering harian. Air lindian yang keluar akan diukur nilai $\mathrm{pH}$, TDS dan DHL. Pengukuran nilai pH menggunakan metode Potensiometri berdasarkan SNI 06-6989.11-2004. Untuk pengukuran nilai TDS dan DHL menggunakan metode Konduktometri berdasarkan SNI 06-6989.12004. 


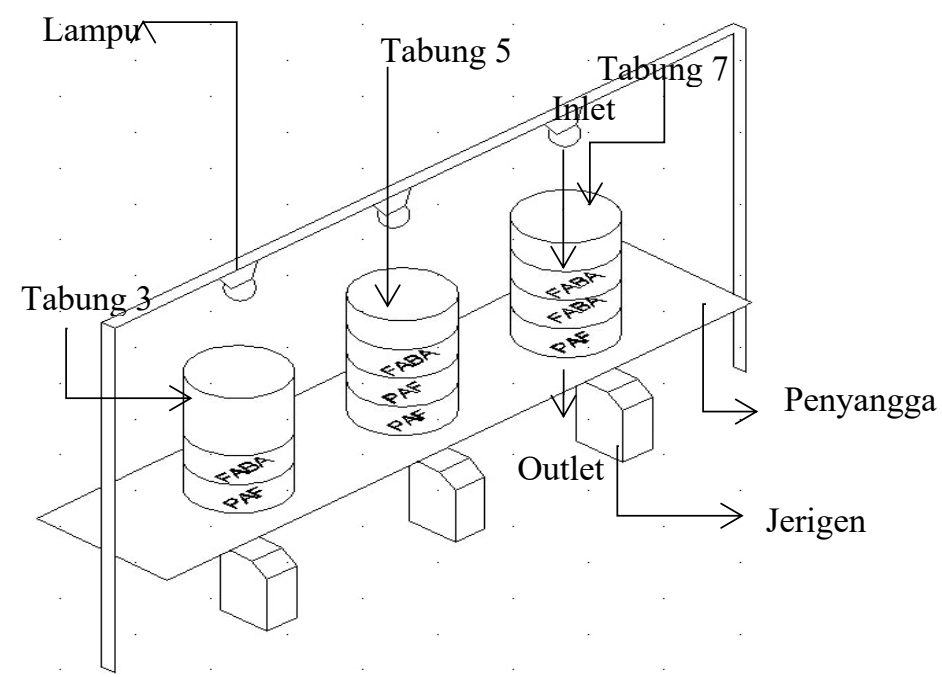

Gambar 2. Skema tabung pencampuran

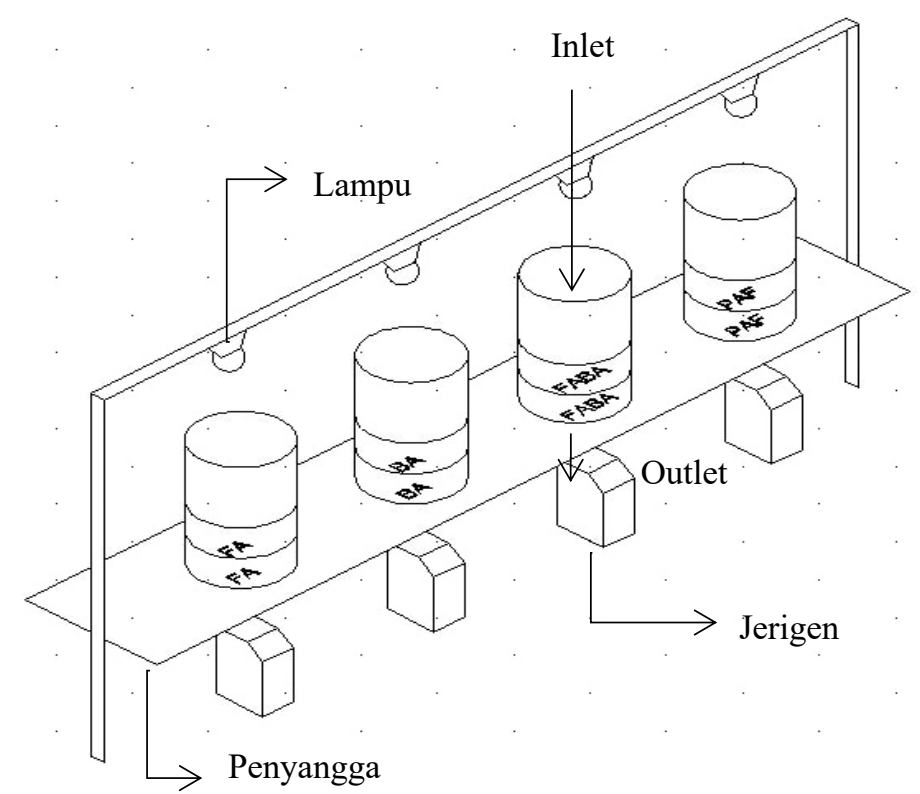

Gambar 3. Skema tabung kontrol

\subsection{Analisis Data}

Analisis data pada penelitian ini dilakukan dengan membandingkan hasil dari perubahan kualitas air setiap variasi dan dengan pengujian secara statistik. Perubahan nilai $\mathrm{pH}$, TDS dan DHL dari masingmasing tabung dibandingkan untuk mengetahui kualitas air terbaik yang dihasilkan. Pengujian secara statistik dilakukan dengan aplikasi SPSS untuk mengetahui apakah terdapat perbedaan rata-rata kualitas air yang dihasilkan dengan menggunakan perbedaan variasi perlakuan sampel NAF. Pengujian perbedaan dalam penelitian ini dilakukan dengan menggunakan uji beda statistik nonparametrik karena beberapa alasan sebagai berikut:

1. Data variasi pelapisan terdiri dari 2 populasi data dengan distribusi data yang didapatkan adalah tidak berdistribusi normal. Ketika data tidak berdistribusi normal maka uji beda dilakukan dengan metode uji statistik Mann Whitney.

2. Data variasi perbedaan ketebalan lapisan FABA dan PAF terdiri dari 3 populasi data dengan 
distribusi data yang didapatkan ditemukan salah satu data tidak berdistribusi normal. Ketika data penelitian tidak berdistribusi normal populasi data terdiri dari 3 sampel maka dapat digunakan uji Kruskal-Wallis.

Perubahan fisik sampel akibat dari siklus basah kering juga dianalisis untuk mengetahui hubungan antara perubahan fisik sampel terhadap kualitas air yang dihasilkan.

\section{HASIL DAN PEMBAHASAN}

\subsection{Perubahan Fisik Sampel}

Perubahan fisik sampel yang terjadi pada masing-masing tabung kontrol dapat dilihat sebagai berikut:

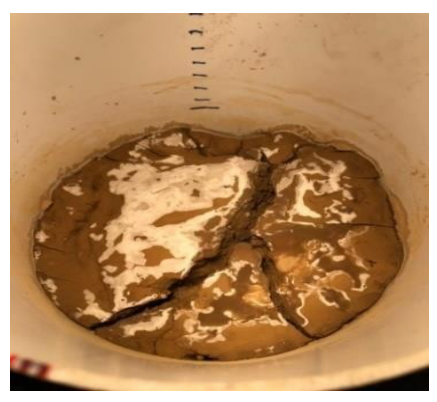

(a) Fly Ash

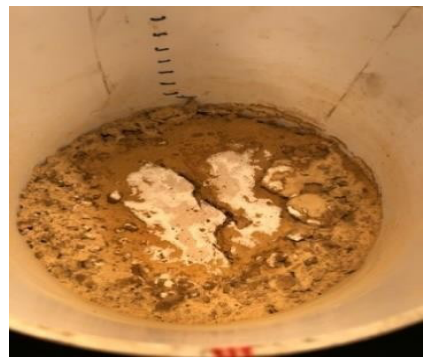

(c) Campuran FABA

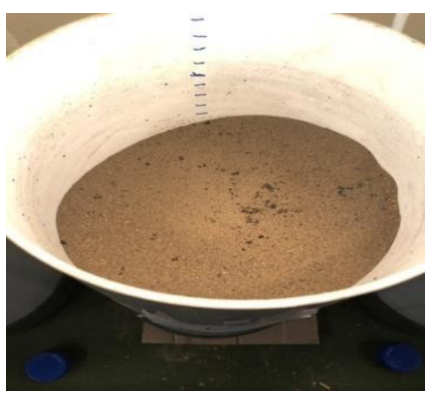

(b) Bottom Ash

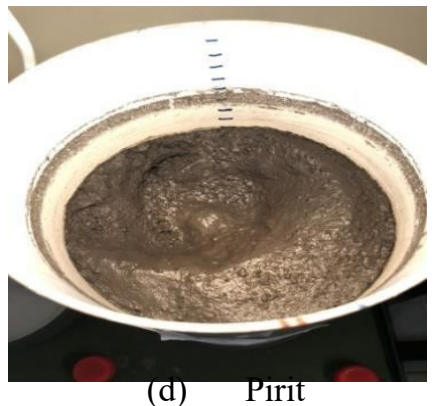

Gambar 4. Kondisi di tabung control

Pada tabung kontrol fly ash, terbentuk crack yang terjadi akibat dari penyiraman aquades dan penyinaran dengan lampu secara terus menerus atau siklus basah-kering. Bagian permukaan merupakan lapisan pertama yang terkena siklus penyiraman dan juga pemanasan dengan lampu sehingga akan terjadi pelapukan khususnya pada bagian permukaan. Pemuaian ini yang menyebabkan terbentuknya crack terutama pada lapisan atas tabung. Perubahan lain yang terjadi selama siklus basah-kering dalam penelitian pada sampel fly ash adalah butiran fly ash yang menjadi lebih halus dan lebih padat. Ukuran butiran yang lebih halus akan mengurangi volume pori-pori batuan sehingga infiltrasi air dan oksigen yang masuk kedalam batuan akan terhambat [3].

Pada tabung kontrol bottom ash, tidak terjadi crack seperti yang terjadi pada tabung kontrol fly ash. Hal ini karena bottom ash memiliki karakteristik butiran yang bersifat seperti pasir sehingga tidak mudah untuk mengalami pemuaian. Hal ini juga didukung dengan hasil penelitian sebelumnya yang dilakukan oleh Lestari (2010) dimana hasil pada penelitian tersebut menunjukkan bahwa bottom ash memiliki sifat yang keras dan susah terlapukkan, sehingga pelapukan yang terjadi akan lebih lambat dibandingkan dengan fly ash [4].

Perubahan fisik material yang terjadi pada tabung kontrol campuran FABA menunjukkan terjadinya perubahan ukuran butiran yang semakin kecil dan padat. Bagian permukaan tabung juga terjadi crack 
yang terjadi seperti pada tabung kontrol fly ash, tetapi crack yang terbentuk tidak sebesar pada crack yang terjadi pada tabung kontrol fly ash. Crack yang terbentuk diprediksi berasal dari material fly ash yang memiliki karakteristik butiran yang bersifat clay.

Pada tabung kontrol pirit, perubahan fisik yang terlihat yaitu terjadinya perubahan ukuran butiran menjadi semakin kecil dan halus. Hal ini dikarenakan dengan siklus basah kering mengakibatkan pelapukan pada material pirit yang mengakibatkan ukuran butir batuan menjadi lebih kecil. Ukuran butiran yang semakin kecil akan meningkatkan luas total permukaan reaktif dari batuan.

\subsection{Analisis Mineralogi X-Ray Diffraction dan X-Ray Fluoresence}

Dari hasil analisa mineralogi menggunakan uji XRD dan XRF yang dilakukan oleh Nugraha et. al., (2020) beberapa catatan penting adalah sebagai berikut:

- Kandungan $\mathrm{CaO}$ pada material FA dan $\mathrm{BA}$ cukup tinggi. Kandungan $\mathrm{CaO}$ pada sampel FA terdeteksi sebesar 24,2\% dan pada BA sebesar 19,4\%. Keberadaan mineral ini mengindikasikan adanya kandungan penetral pada sampel uji. Kandungan $\mathrm{Ca}$ adalah sumber alkalinitas sebagai sumber penetral asam.

- Tingginya kandungan $\mathrm{S}$ pada material FA dapat berasal dari $\mathrm{SO}_{2}$ yang bereaksi dengan air di udara. Sedangkan pada material BA, kandungan S lebih kecil karena merupakan abu dasar. Konsentrasi nilai S pada material FA adalah sebesar 4,64\% dan pada BA sebesar 0,73\%.

- Kandungan S pada PAF berkaitan dengan mineral pirite $\left(\mathrm{FeS}_{2}\right)$ dengan konsentrasi nilai $\mathrm{S}$ sebesar $8,52 \%$. Tingginya kandungan $\mathrm{Al}$ pada material PAF berasal dari mineral sekunder seperti kaolinite $\mathrm{Al}_{2}\left(\left(\mathrm{Si}_{2} \mathrm{O}_{5}\right)(\mathrm{OH})_{4}\right)$.

\subsection{Analisa Kualitas Air Tabung Pelapisan NAF}

Pada sistem ini, material NAF berfungsi membatasi masuknya oksigen sehingga oksigen yang masuk ke lapisan PAF dibawahnya akan berkurang. Penutupan dengan material NAF ini bertindak sebagai barrier untuk mencegah terjadinya kontak mineral pirit dengan air dan oksigen. Hasil kualitas air yang dihasilkan dari skenario uji pelapisan dapat dilihat pada pembahasan berikut:

Perubahan nilai $\mathrm{pH}$ pada tabung pelapisan NAF fly ash dan bottom ash dapat dilihat sebagai berikut:

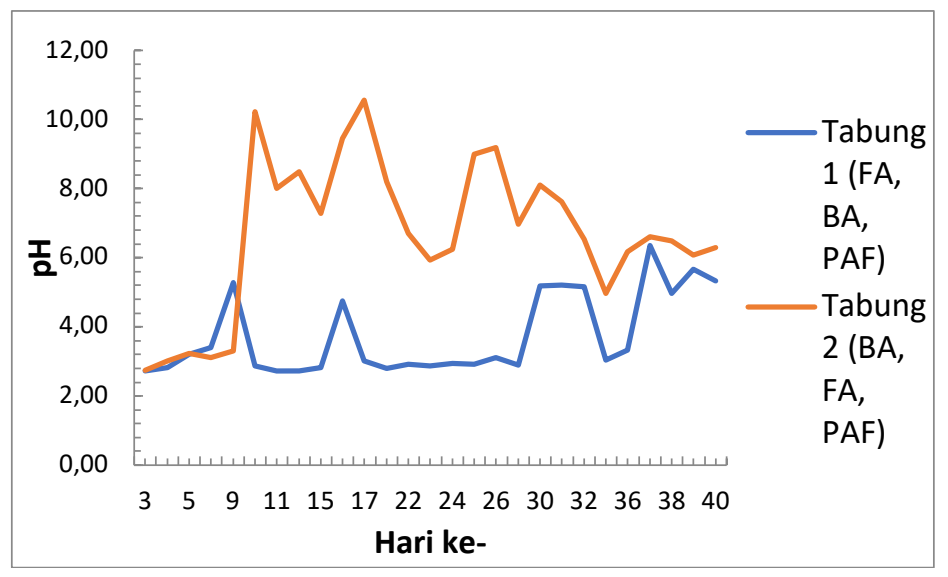

\section{Gambar 5. Grafik perbandingan perubahan nilai pH pada kolom pelapisan}

Pada sistem pelapisan, lapisan paling atas tabung merupakan lapisan pelembab (moisture) yang menghalangi masuknya air dan oksigen sehingga oksidasi sulfida didalam pirit akan terhambat. Sedangkan pada lapisan tengah, merupakan lapisan yang menghasilkan penetral alkali [5]. Dengan kandungan alkali yang lebih besar pada fly ash (24,2\%), maka tabung 2 dengan posisi fly ash berada pada lapisan tengah tabung akan menghasilkan lebih banyak mineral alkali untuk menetralkan asam dari oksidasi pirit sehingga nilai $\mathrm{pH}$ yang dihasilkan akan lebih besar. Nilai rata-rata $\mathrm{pH}$ yang dihasilkan dari tabung 2 pada awal penelitian adalah sebesar 2,75. Setelah 28 hari, terjadi peningkatan 
nilai pH menjadi 6,29. Hal ini membuktikan bahwa material fly ash diletakkan pada tengah tabung akan lebih efektif untuk menghambat masuknya air dan oksigen untuk masuk ke dalam lapisan reaktif pirit sehingga oksidasi pirit oleh oksigen akan terhambat yang mengakibatkan meningkatnya nilai $\mathrm{pH}$. Untuk perubahan nilai TDS dari sistem pelapisan dapat dilihat pada Gambar 6.

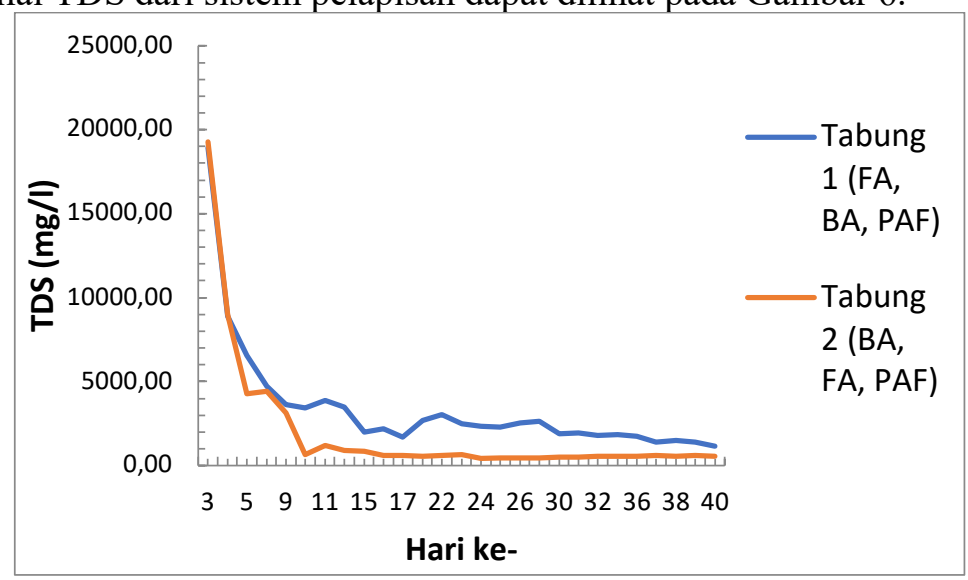

\section{Gambar 6. Grafik perbandingan nilai TDS pada kolom pelapisan}

Berdasarkan Gambar 6, tabung 1 dan 2 menunjukkan penurunan nilai TDS pada kedua tabung. Nilai TDS sangat berkaitan dengan perubahan $\mathrm{pH}$ dimana pada $\mathrm{pH}$ yang rendah ion dan logam akan terlarut. Ion dan logam yang terlarut ini akan meningkatkan nilai total padatan terlarut atau TDS air lindian [1]. Tabung 1 memiliki nilai $\mathrm{pH}$ yang lebih rendah daripada tabung 2. Kondisi $\mathrm{pH}$ rendah pada tabung 1 ini mengakibatkan total padatan terlarut yang dihasilkan akan lebih besar. tabung 1 ini mengakibatkan padatan terlarut yang dihasilkan akan lebih besar dari tabung 2, karena semakin rendah $\mathrm{pH}$ maka semakin meningkat nilai TDS [1]. Dilihat dari perubahan nilai TDS pada tabung 1 dan tabung 2, terjadi penurunan nilai TDS yang konstan pada hari 9 hingga hari ke 28. Penurunan nilai TDS ini dikarenakan sampel didalam tabung telah berada dalam kondisi jenuh sehingga konsentrasi oksigen dan air yang masuk ke lapisan reaktif pirit akan sangat minim. Akibatnya, nilai $\mathrm{pH}$ pada air lindian akan meningkat sehingga nilai TDS yang dihasilkan akan berkurang. Perbedaan perubahan nilai TDS dari tabung 1 dan 2 adalah pada tabung 2, penurunan nilai TDS terjadi lebih cepat dibandingkan dengan tabung 1. Hal ini dipengaruhi oleh perubahan nilai $\mathrm{pH}$, dimana pada tabung 2 terjadi peningkatan nilai $\mathrm{pH}$ yang lebih cepat sehingga penurunan nilai TDS dari tabung 2 juga akan lebih cepat.

Perubahan nilai DHL dari tabung 1 dan tabung 2 dapat dilihat pada Gambar 7 berikut:

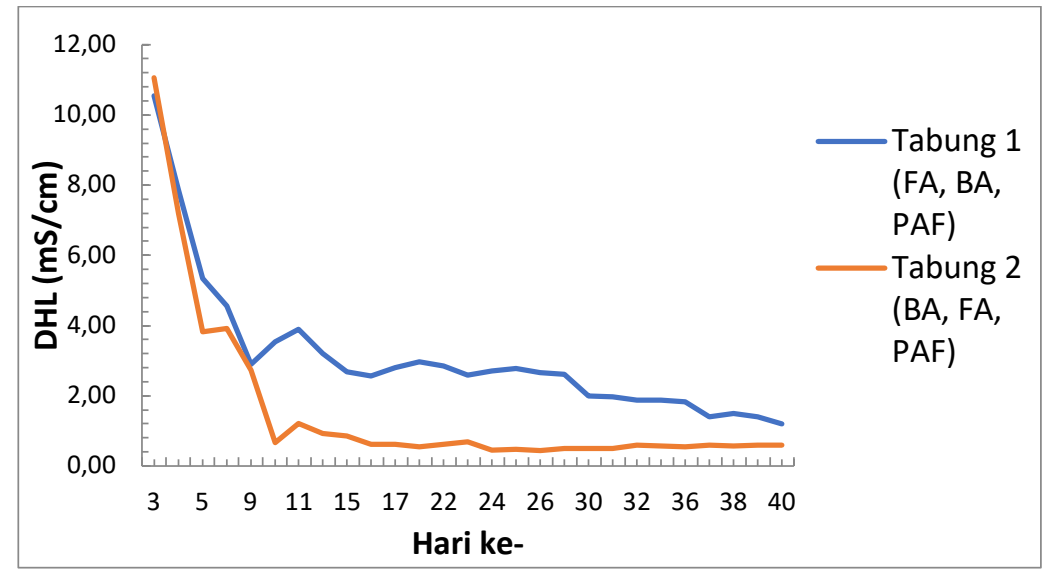

Gambar 7. Grafik perbandingan perubahan nilai DHL kolom pelapisan 
Nilai DHL pada tabung 1 lebih tinggi dibandingkan dengan tabung 2. Perubahan nilai DHL berbanding lurus dengan perubahan nilai TDS. Semakin besar padatan atau logam yang terlarut, maka akan meningkatkan kemampuan suatu larutan untuk dapat menghantarkan arus listrik [2]. Dari Gambar 10, diketahui bahwa perubahan nilai DHL dari masing-masing tabung selama penelitian mengalami penurunan. Perubahan nilai DHL ini sama dengan perubahan yang terjadi pada parameter TDS. Penurunan nilai DHL disebabkan karena sampel telah berada dalam kondisi jenuh sehingga konsentrasi oksigen dan air yang masuk ke lapisan reaktif pirit akan sangat minim yang menyebabkan nilai $\mathrm{pH}$ pada air lindian akan meningkat. Akibatnya nilai DHL yang dihasilkan akan berkurang. Tabung 1 memiliki $\mathrm{pH}$ yang lebih rendah dari tabung 2 sehingga akan lebih banyak logam yang terlarut. Dengan $\mathrm{pH}$ yang rendah, akan lebih banyak logam yang terlarut sehingga menghasilkan ionion dilarutan yang dapat menghantarkan arus listrik.

\subsection{Analisa Kualitas Air Tabung Pencampuran}

Pengujian lainnya dilakukan dengan membuat skenario pencampuran material NAF fly ash dan bottom ash. Kemudian dilakukan perlakuan perbedaan ketebalan dari material campuran FABA dan material PAF pirit. Hasil kualitas air pH, TDS dan DHL yang dihasilkan dari skenario pencampuran NAF FABA dan PAF pirit dapat dilihat pada pembahasan berikut:

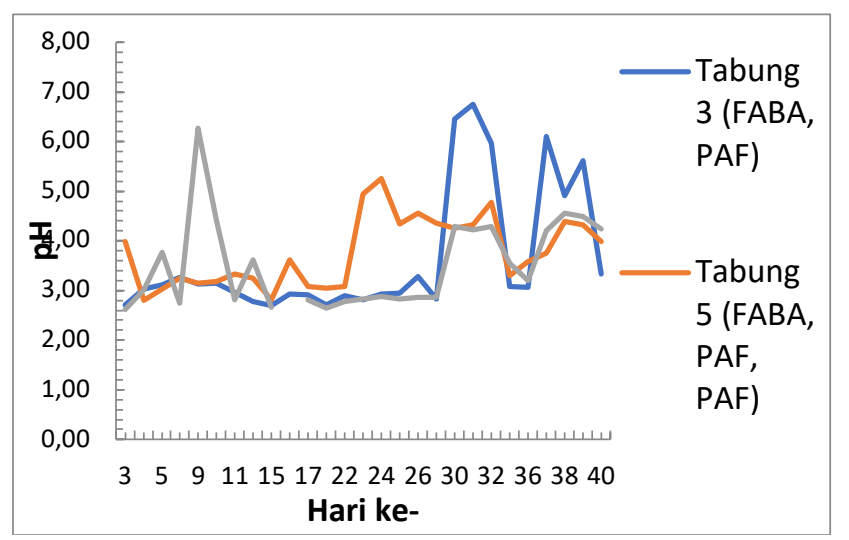

\section{Gambar 8. Grafik perbandingan perubahan nilai pH kolom ketebalan}

Rendahnya nilai $\mathrm{pH}$ pada tabung 3 dan 7 disebabkan karena terbentuknya rekahan yang mengakibatkan bertambahnya kapasitas oksigen didalam tabung. Dalam kondisi jenuh, reaktivitas pirit dipengaruhi oleh konsentrasi dan transport oksigen dalam air [1]. Penyiraman harian yang terus dilakukan akan membawa udara yang terperangkap didalam rekahan masuk hingga ke lapisan reaktif sulfida didasar tabung. Akibatnya pirit akan teroksidasi sehingga menghasilkan keasaman yang menurunkan nilai $\mathrm{pH}$ air. Rekahan yang terbentuk pada tabung 3 dan 7 dapat dilihat pada gambar berikut:

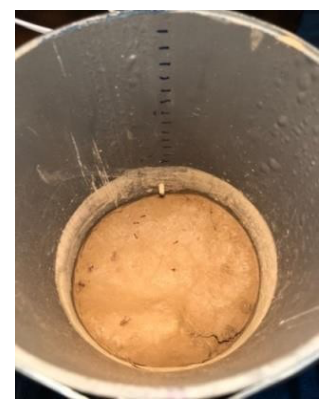

(a) Tabung 3

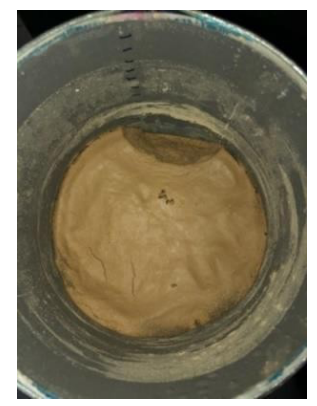

(b) Tabung 7

Gambar 9. Kondisi rekahan tabung 
Sedangkan pada tabung 5, rendahnya nilai $\mathrm{pH}$ diakibatkan karena komposisi lapisan PAF yang lebih besar dari campuran FABA yaitu 2:1. Akibatnya, penetral dari FABA belum mampu untuk menetralkan keasaman yang dihasilkan dari oksidasi PAF pirit dalam tabung. Dari grafik perubahan nilai TDS, terjadi peningkatan nilai $\mathrm{pH}$ pada hari ke 25-26, hal ini dapat dikarenakan kondisi sampel yang sudah jenuh sehingga oksigen dan air tidak dapat masuk yang mengakibatkan oksidasi pirit terhambat sehingga nilai $\mathrm{pH}$ meningkat. Nilai $\mathrm{pH}$ kemudian fluktuatif dihari berikutnya. Hal ini dikarenakan rekahan yang terbentuk dipermukaan tabung mengakibatkan oksigen dapat masuk ke dalam lapisan reaktif pirit. Akibatnya laju oksidiasi pirit meningkat sehingga nilai $\mathrm{pH}$ kembali menurun. Nilai $\mathrm{pH}$ kemudian kembali meningkat dapat disebabkan karena kondisi sampel dalam tabung berada dalam kondisi jenuh kembali.

Perubahan nilai TDS pada tabung pencampuran dapat dilihat pada grafik berikut:

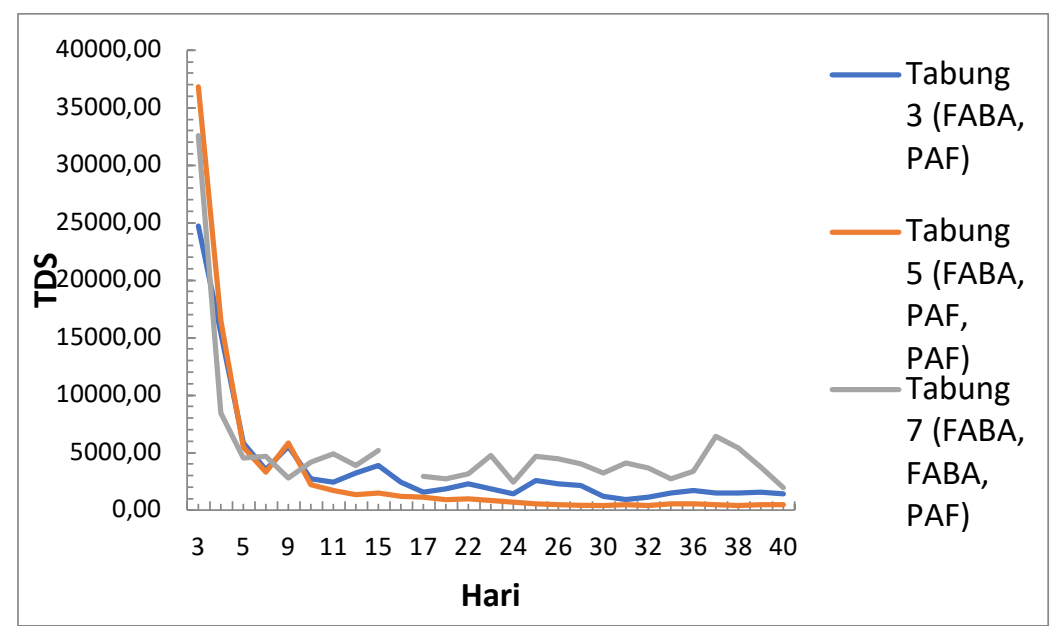

\section{Gambar 10. Grafik perbandingan perubahan nilai TDS kolom ketebalan}

Nilai TDS pada tabung 3 dan 7 masih cukup tinggi dibandingkan dengan tabung 5 selama percobaan. Hal ini dikarenakan $\mathrm{pH}$ yang rendah akibat dari oksidasi pirit didalam tabung sehingga banyak ion dan logam dari PAF akan terlarut. Faktor lain yang diprediksi yaitu karena penggunaan FABA yang lebih banyak menghasilkan nilai TDS yang lebih tinggi karena pada kandungan FABA memiliki lebih banyak ash yang berukuran kecil dan halus sehingga lebih mudah terlarut.

Nilai TDS pada tabung 5 merupakan nilai terkecil dari 2 tabung lainnya. Hal ini disebabkan karena jumlah ash yang digunakan lebih sedikit. Selain itu, pirit didalam tabung 5 mengalami oksidasi yang lebih lambat dibandingkan 2 tabung lainnya karena tidak terdapat rekahan dilapisan atasnya. Dengan kondisi minim oksigen didalam tabung maka asam hasil oksidasi pirit pada lapisan tengah tabung bisa ternetralkan sehingga diprediksi $\mathrm{pH}$ air pada lapisan tengah akan lebih tinggi. Karena $\mathrm{pH}$ air yang lebih tinggi pada lapisan tengah tabung, maka kandungan ion dan logam pada lapisan tengah tidak terlarut. Air kemudian mengalir melewati lapisan PAF didasar tabung dengan membawa kandungan alkali yang telah berkurang untuk menetralkan keasaman dari oksidasi pirit pada lapisan tengah tabung. Sisa alkali tersebut tidak cukup untuk menetralkan asam hasil oksidasi pirit yang terjadi didasar tabung sehingga $\mathrm{pH}$ air kembali menurun yang mengakibatkan ion dan logam dilapisan PAF dasar tabung akan terlarut. Hal inilah yang diprediksi menjadi penyebab rendahnya nilai TDS pada tabung 5. Rendahnya nilai TDS pada tabung 5 diprediksi karena dibagian PAF dasar tabung saja yang menghasilkan ion dan logam terlarut pada lindian.

Reaksi penetralan asam hasil oksidasi pirit dengan kondisi minim oksigen adalah sebagai berikut:

$$
\mathrm{CaO}+\mathrm{H}_{2} \mathrm{O} \rightarrow \mathrm{Ca}(\mathrm{OH})_{2}
$$


Kandungan Lime $(\mathrm{CaO})$ dari material fly ash dan bottom ash dalam kondisi minim oksigen akan bereaksi dengan air menghasilkan Kalsium Hidroksida $\mathrm{Ca}(\mathrm{OH})_{2}$. Kalsium Hidroksida yang terbentuk ini kemudian akan menetralkan keasaman hasil oksidasi pirit. Reaksi penetralan yang terjadi adalah sebagai berikut:

$$
\mathrm{H}^{+}+\mathrm{Ca}(\mathrm{OH})_{2} \rightarrow \mathrm{H}_{2} \mathrm{O}+\mathrm{Ca}^{2+}
$$

Keasaman hasil oksidasi pirit kemudian akan berekasi dengan Kalsium Hidroksida. Hasil reaksi tersebut adalah Hidrogen Dioksida dan Kalsium [2]. Karena keasaman yang dihasilkan sedikit, maka kandungan logam terlarut yang dihasilkan juga akan sedikit.

Untuk perubahan nilai DHL dari tabung pencampuran dapat dilihat pada grafik berikut:

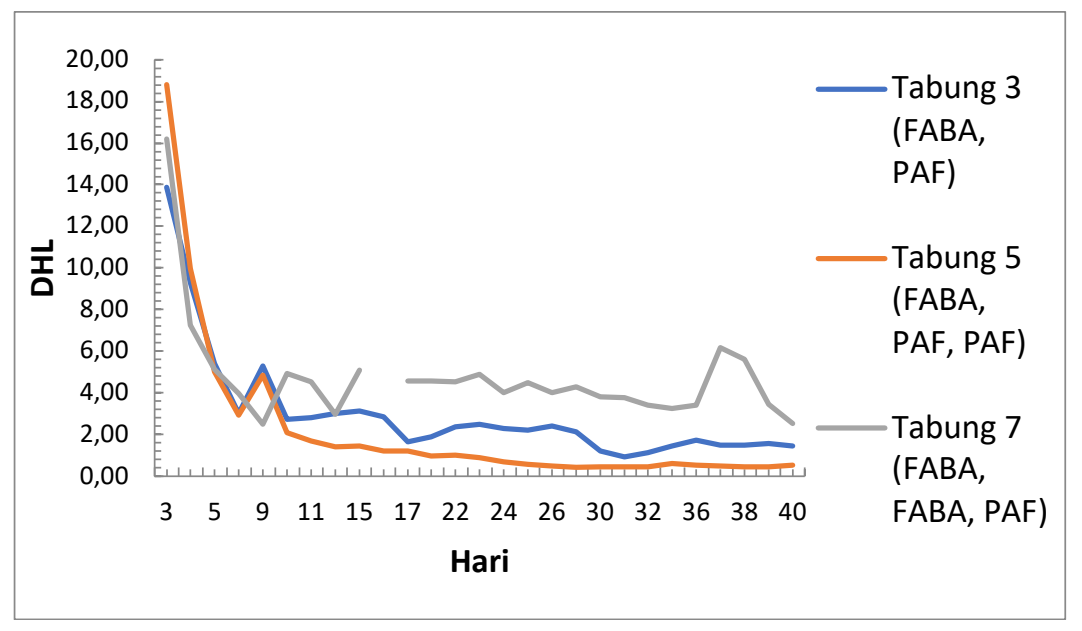

\section{Gambar 11. Grafik perbandingan perubahan nilai DHL kolom ketebalan}

Dari grafik perubahan nilai DHL, diketahui bahwa tabung 3, 5 dan 7 mengalami penurunan hingga diakhir penelitian. Walaupun terjadi penurunan, nilai DHL dari ketiga tabung masih menunjukkan nilai yang cukup tinggi hingga akhir penelitian. Pada tabung 3 nilai DHL pada pengukuran awal yaitu $13,88 \mathrm{mS} / \mathrm{cm}$ dan DHL akhir yaitu $1,47 \mathrm{mS} / \mathrm{cm}$. Pada tabung 5 nilai DHL pada pengukuran awal yaitu $18,81 \mathrm{mS} / \mathrm{cm}$ dan pada pengukuran DHL akhir yaitu $0,53 \mathrm{mS} / \mathrm{cm}$. Pada tabung 7 nilai DHL pada pengukuran awal yaitu $16,20 \mathrm{mS} / \mathrm{cm}$ dan pada pengukuran DHL akhir yaitu $2,52 \mathrm{mS} / \mathrm{cm}$. Tingginya nilai DHL dari ketiga tabung disebabkan karena rendahnya nilai $\mathrm{pH}$ sehingga melarutkan logamlogam dari material yang digunakan. Logam-logam terlarut tersebut akan menghasilkan ion yang bergerak bebas sehingga menghasilkan arus listrik. Penurunan nilai DHL dari ketiga tabung mulai terlihat dari hari ke-7 dan kemudian cenderung mengalami fluktuatif perunbahan nilai DHL hingga di akhir penelitian. Penurunan nilai DHL dari ketiga tabung ini dapat disebabkan karena kandungan ion dan logam yang terkandung dari masing-masing sampel didalam tabung telah terlarut dihari sebelumnya. Akibatnya ion dan logam di hari berikutnya akan lebih kecil dari hari sebelumnya sehingga nilai DHL juga berkurang.

\subsection{Analisis Data Secara Statistik Tabung Pelapisan}

Analisis statistik pada penelitian ini menggunakan uji beda non-parametrik dikarenakan distribusi data hasil uji normalitas menunjukkan data yang digunakan tidak berdistribusi dengan normal. Pada penelitian ini uji beda yang digunakan yaitu uji Mann Whitney untuk data dengan 2 sampel. Sedangkan untuk data dengan 3 sampel digunakan uji Kruskall-Wallis. Hipotesis awal yang digunakan pada penelitian ini adalah:

$\mathrm{Ha}=$ Ada perbedaan kualitas air dengan perbedaan perlakuan pelapisan. 
Pengambilan keputusan pada uji Mann Whitney adalah sebagai berikut:

1. Jika nilai signifikansi atau (Asymp. Sig. (2-tailed) $<0,05$ maka hipotesis (Ha) diterima.

2. Jika nilai signifikansi atau (Asymp. Sig (2-tailed) $>0,05$ maka hipotesis (Ha) ditolak.

Hasil analisis uji beda non-parametrik Uji Mann Whitney parameter $\mathrm{pH}$ pada tabung pelapisan dapat dilihat pada pembahasan berikut (Tabel 2):

Tabel 2. Hasil uji beda Mann Whitney tabung pelapisan parameter $\mathrm{pH}$

\begin{tabular}{cc}
\hline \multicolumn{2}{c}{ Kualitas Air (pH) } \\
\hline Mann-Whitney & 85,500 \\
Asymp. Sig. (2-tailed) & 0,000 \\
\hline
\end{tabular}

Nilai Asymp. Sig. (2-tailed) $0,000<$ dari nilai probabilitas 0,05 maka dapat disimpulkan bahwa Ha diterima. Dengan demikian dapat dikatakan ada perbedaan nilai $\mathrm{pH}$ dengan perbedaan perlakuan pelapisan sampel fly ash dan bottom ash.

Hasil uji beda Mann Whitney dari tabung pelapisan parameter TDS dapat dilihat pada tabel 3 berikut:

Tabel 3. Hasil uji beda Mann Whitney tabung pelapisan parameter TDS

\begin{tabular}{cc}
\hline \multicolumn{2}{c}{ Kualitas Air (TDS) } \\
\hline Mann-Whitney & 119,000 \\
Asymp. Sig. (2-tailed) & 0,000 \\
\hline
\end{tabular}

Nilai Asymp. Sig. (2-tailed) sebesar $0,000<$ dari nilai probabilitas 0,05 maka dapat disimpulkan bahwa Ha diterima. Dengan demikian dikatakan bahwa ada perbedaan nilai TDS dengan perbedaan perlakuan pelapisan sampel fly ash dan bottom ash.

Hasil uji beda Mann Whitney parameter DHL dari tabung pelapisan dapat dilihat pada tabel 4 berikut:

Tabel 4. Hasil uji beda Mann Whitney tabung pelapisan parameter DHL

\begin{tabular}{cc}
\hline \multicolumn{2}{c}{ Kualitas Air (DHL) } \\
\hline Mann-Whitney & 112,500 \\
Asymp. Sig. (2-tailed) & 0,000 \\
\hline
\end{tabular}

Nilai Asymp. Sig. (2-tailed) sebesar $0,000<$ dari nilai probabilitas 0,05 maka dapat disimpulkan bahwa Ha diterima. Dengan demikian dapat dikatakan ada perbedaan nilai DHL dengan perbedaan perlakuan pelapisan sampel fly ash dan bottom ash.

\subsection{Analisis Data Secara Statistik Tabung Pencampuran}

Uji Kruskall-Wallis digunakan pada analisis tabung pencampuran karena data yang digunakan lebih dari 2 sampel yang tidak saling berpasangan. Uji ini digunakan ketika distribusi data yang digunakan tidak berdistribusi normal. Pedoman pengambilan keputusan pada Uji Beda Kruskall- Wallis adalah sebagai berikut: 
1. Jika nilai Asymp.Sig $>0,05$ maka tidak ada perbedaan atau Ho diterima.

2. Jika nilai Asymp.Sig $<0,05$ maka ada perbedaan atau Ho ditolak. Hipotesis awal yang digunakan pada pengujian iniadalah:

Ho : Tidak ada perbedaan kualitas air dengan perbedaan ketebalan lapisan campuran FABA dan PAF. Ha : Ada perbedaan kualitas air dengan perbedaan ketebalan lapisan campuran FABA dan PAF.

Hasil Uji Beda Kruskall-Wallis parameter pH pada tabung pencampuran dapat dilihat pada tabel 5 berikut:

Tabel 5. Hasil uji beda Kruskall-Wallis tabung pencampuran parameter pH

\begin{tabular}{cc}
\hline \multicolumn{2}{c}{ Kualitas Air (pH) } \\
\hline Kruskall-Wallis & 5,549 \\
Asymp.Sig. & 0,062 \\
\hline
\end{tabular}

Nilai Asymp.Sig sebesar 0,062 >0,05. Dengan demikian dapat dikatakan bahwa Ho diterima yang berarti tidak ada perbedaan nilai $\mathrm{pH}$ dengan perbedaan perlakuan ketebalan lapisan FABA dan PAF. Hal ini dapat terlihat dari rata-rata perubahan nilai $\mathrm{pH}$ pada tabung 3, 5 dan 7 yang menunjukkan perbedaan nilai yang tidak terlalu besar diantara ketiganya dimana pada tabung 3 nilai rata-rata $\mathrm{pH}$ didapatkan sebesar 3,64 serta pada tabung 5 dan 7 berturut-turut sebesar 3,77 dan 3,52.

Hasil Uji Beda Kruskall-Wallis parameter TDS pada tabung pencampuran dapat dilihat pada tabel 6 berikut:

Tabel 6. Hasil uji beda Kruskall-Wallis tabung pencampuran parameter TDS

\begin{tabular}{cc}
\hline \multicolumn{2}{c}{ Kualitas Air (TDS) } \\
\hline Kruskall-Wallis & 28,698 \\
Asymp.Sig. & 0,000 \\
\hline
\end{tabular}

Nilai Asymp.Sig sebesar $0,000<0,05$. Dengan demikian dapat dikatakan bahwa Ho ditolak yang berarti ada perbedaan nilai TDS dengan perbedaan perlakuan ketebalan lapisan FABA dan PAF. Dilihat dari nilai rata-rata TDS masing-masing tabung, hasil yang didapatkan menunjukkan nilai yang sangat berbeda jauh dari tiap tabung. Tabung 3 menghasilkan nilai TDS sebesar 3534,56 mg/l, tabung 5 menghasilkan nilai TDS sebesar 3191,56 dan tabung 7 menghasilkan nilai TDS terbesar yaitu sebesar 5130,48 mg/1 sehingga memberikan perbedaan nilai TDS yang dihasilkan.

Hasil Uji Beda Kruskall-Wallis parameter DHL pada tabung pencampuran dapat dilihat pada tabel 7 berikut:

Tabel 7. Hasil uji beda Kruskall-Wallis tabung pencampuran parameter DHL

\begin{tabular}{lc}
\hline \multicolumn{2}{c}{ Kualitas Air (DHL) } \\
\hline Kruskall-Wallis & 33,384 \\
Asymp.Sig. & 0,000 \\
\hline
\end{tabular}

Nilai Asymp.Sig sebesar 0,000 <0,05. Dengan demikian dapat dikatakan bahwa Ho ditolak yang berarti ada perbedaan nilai DHL dengan perbedaan perlakuan ketebalan lapisan FABA dan PAF. Nilai DHL rata-rata pada masing-masing tabung 3, 5 dan 7 berturut-turut adalah sebesar 3,06 mS/cm, 2,23 $\mathrm{ms} / \mathrm{cm}$ dan $4,69 \mathrm{mS} / \mathrm{cm}$. 


\subsection{Perbandingan Sistem Pelapisan dan Ketebalan}

Dari hasil uji kinetik variasi perlakuan pelapisan dan pencampuran material NAF dan PAF dengan menggunakan uji kolom pelindian, didapatkan hasil bahwa perlakuan pelapisan memiliki kualitas air yang lebih baik. Material NAF pada sistem pelapisan yang berada diatas material PAF berfungsi sebagai penghalang dalam masuknya oksigen ke lapisan reaktif PAF. Dan lapisan kedua merupakan lapisan yang menghasilkan penetral alkali untuk menetralkan AAT yang terbentuk dilapisan dasar tabung. Faktor penting yang berpengaruh terhadap pembentukan AAT dalam sistem pelapisan adalah pelapukan batuan. Pelapukan yang terjadi pada lapisan NAF akan memperkecil permeabilitas butiran dan menyebabkan lapisan jenuh air sehingga akan berakibat pada penurunan permeabilitas. Lapisan yang jenuh air akan menghambat masuknya oksigen sehingga dapat mengurangi laju reaksi oksidasi pirit.

Pada variasi pencampuran FABA, kualitas air yang dihasilkan masih jauh dari yang diharapkan. Campuran FABA tidak dapat menahan siklus basah kering sehingga mengakibatkan pemuaian pada lapisan teratas tabung. Ini dibuktikan dengan terbentuknya rekahan yang terjadi pada tabung pencampuran FABA. Rekahan yang terbentuk akan menambah konsentrasi oksigen didalam tabung yang dapat berakibat meningkatnya laju oksidasi pirit didalam tabung. Akibatnya, nilai $\mathrm{pH}$ yang dihasilkan akan menjadi asam sehingga ion dan logam akan terlarut. Hasil perbandingan kualitas air pada sistem pelapisan dan pencampuran dapat dilihat sebagai berikut (Gambar 12 - 14):

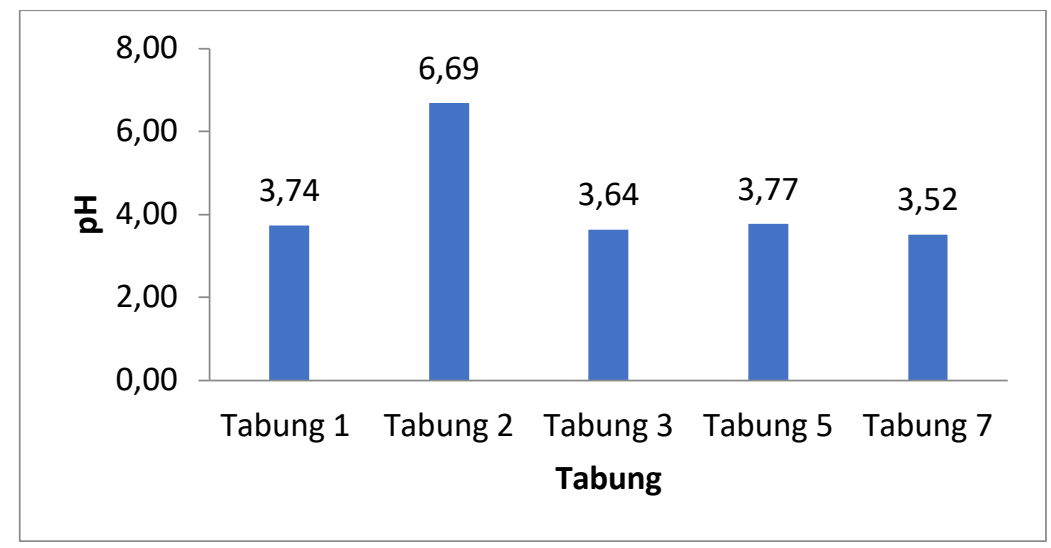

Gambar 12. Grafik perbandingan perubahan nilai pH kolom pelapisan dengan kolom ketebalan

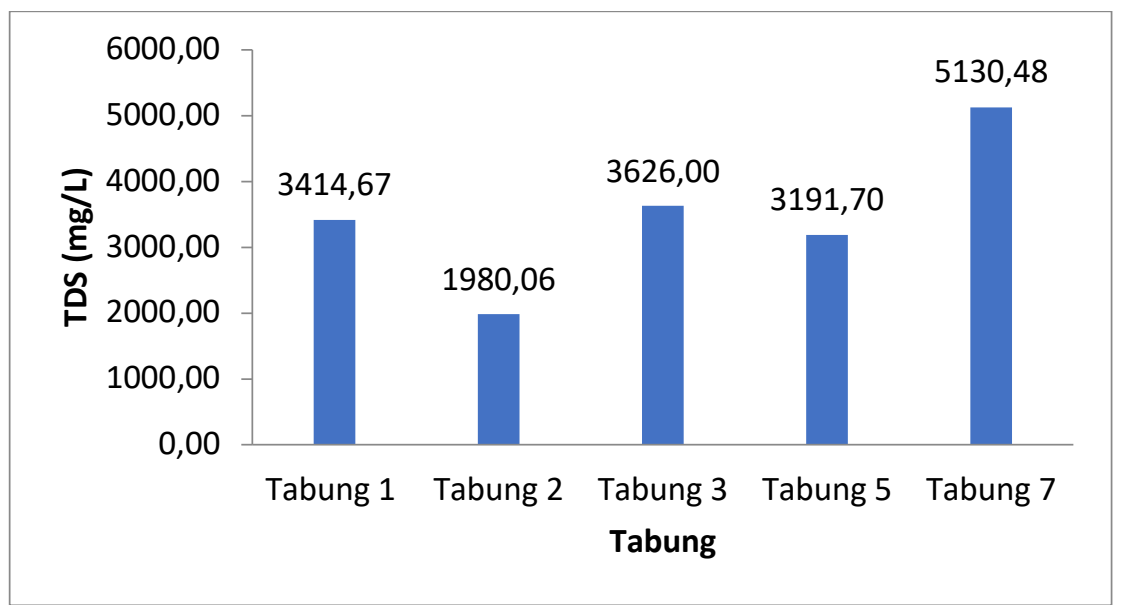

Gambar 13. Grafik perbandingan perubahan nilai TDS kolom pelapisan dengan kolom ketebalan 


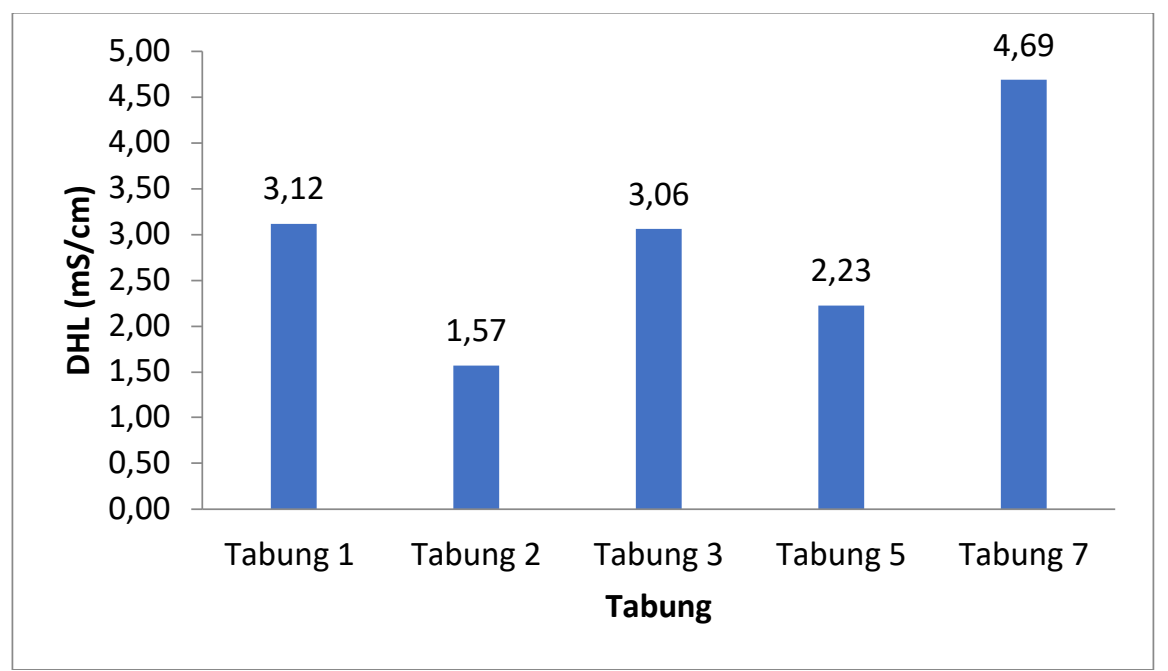

\section{Gambar 14. Grafik perbandingan perubahan nilai DHL kolom pelapisan dengan kolom ketebalan}

\section{KESIMPULAN}

Penggunaan material fly ash dan bottom ash sebagai cover dapat menghambat terbentuknya air asam tambang dengan cara menghambat masuknya air dan oksigen ke lapisan reaktif pirit. Penggunakan fly ash dan bottom ash dapat meningkatkan nilai $\mathrm{pH}$, menurunkan nilai TDS serta DHL dari air lindian yang dihasilkan karena sifat dari fly ash dan bottom ash yang bersifat basa. Selain bersifat basa, NAF yang digunakan terutama fly ash memiliki ukuran butiran yang kecil $(0,075 \mathrm{~mm})$ dan halus sehingga akan sangat mudah mengalami kejenuhan didalam batuan yang dapat menghambat terbentuknya air asam tambang [6]. Berdasarkan pengukuran kualitas air lindian dengan parameter $\mathrm{pH}$, TDS dan DHL maka didapatkan perlakuan dengan variasi perbedaan posisi fly ash dan bottom ash pada tabung 2 menghasilkan kualitas air paling baik dibandingkan dengan tabung lainnya.

\section{DAFTAR PUSTAKA}

[1] Gautama, R. S. (2019). "Pembentukan, Pengendalian dan Pengelolaan Air Asam Tambang", ITB: ITB Press, Bandung, Indonesia.

[2] Herlina, A., Handayani, H. E., \& Iskandar, H. (2014). "Pengaruh Fly Ash dan Kapur Tohor pada Netralisasi Air Asam Tambang Terhadap Kualitas Air Asam Tambang (Ph, Fe \& Mn) di Iup Tambang Air Laya Pt. Bukit Asam (Persero), Tbk". Jurnal Ilmu Teknik, 2(2).

[3] Nugraha, C., Sukandar, \& Pratama, Y. (2020). "Characterization Study of Coal-Combustion Ash for Acid Mine Drainage Prevention.", Proceeding International Conference on Green Technology and Design.

[4] Lestari, I. (2010). "Studi Perilaku Pelapukan dan Kinetika Lindian Batuan Akibat Penambahan Abu Batubara Untuk Pencegahan Pembentukan Air Asam Tambang”, ITB, Bandung.

[5] Nugraha, C. (2012). "The Importance of Physical Rock Weathering in Acid and Metalliferous Drainage Generation at Waste Rock Dumping Area". Paper presented at the International Acid and Metalliferous Drainage Workshop, Beijing, China.

[6] AMIRA International. (2002). "ARD Test Handbook", Australia. 